\title{
GENERATING ASPECT-ORIENTED VERB PARADIGMS IN MACEDONIAN
}

\author{
Vladimir Cvetkoski \\ Blazhe Koneski Faculty of Philology \\ Sts. Cyril and Methodius University in Skopje \\ Skopje, Macedonia
}

Key words: computational linguistics, aspect-oriented conjugation, verbs, aspect, online conjugator.

Summary: The paper outlines the theoretical background behind a recent online Macedonian aspectual conjugator, located at asp.vigna.mk, by describing the current state of the Macedonian verb system from the perspective of traditional aspect theory. The research on and development of such an online reference resource has been motivated by the lack of descriptions of formal aspect-related problems in textbooks and grammars on contemporary Macedonian.

\section{ГЕНЕРИРАЊЕ НА АСПЕКТНО ОРИЕНТИРАНИ ГЛАГОЛСКИ ПАРАДИГМИ НА МАКЕДОНСКИ}

\author{
Владимир Цветкоски \\ Филолочики факултет ,Блаже Конески“ \\ универзитет „Св. Кирил и Методиј“ \\ Скопје, Македонија
}

Клучни зборови: компјутерска лингвистика, видска конјугација, глаголи, глаголски вид, интернет-конјугатор.

Резиме: Во трудот е изложена теоретската позадина на неодамна објавениот македонски видски конјугатор што се наоѓ на локацијата asp.vigna.mk, претставувајќ́ ја актуелната состојба во македонскиот глаголски систем од аспект на традиционалната видска теорија. Истражувањето и разработката на едно вакво онлајн помагало е мотивирано од недостигот на формални описи на 
видската проблематика како во учебниците така и во граматиките на современиот македонски јазик.

\section{Introduction ${ }^{1}$}

The conjugator has been designed to target one of the most frequent difficulties encountered by foreign learners of Macedonian - the proper distinction and tense formation as well as the proper use of aspect in studying the Macedonian verb system. The following research has been conducted to gather the most relevant and up-to-date information on the current state of affairs in the contemporary Macedonian verb system from the perspective of traditional aspect theory with a view to compiling a reference resource for language students.

As early as the planning phase of the research, it has become clear that this type of resource would prove useful not only to non-Macedonian language learners but also to native ones as descriptions of aspect-related problems have turned out to be underrepresented in current textbooks and grammars on contemporary Macedonian.

This served as our motivation to create an aspectual conjugator (asp.vigna.mk) in addition to our previous commonplace Macedonian conjugator (vigna.mk). We hope the software achieves its goal i.e. to give students of Macedonian a fuller account of the Macedonian verb system with all of its complexities.

\section{Aspectual distinction}

Describing the grammatical category of aspect as a lexical-grammatical one, Kiril Koneski (1999b: 240) has defined it as "a system that includes all the verbs of the Macedonian language, seen as a juxtaposition of two rows of verb forms: perfectives, <..> and imperfectives". In this light, while perfectives express events in their completeness, imperfectives do so in their duration. Iteratives are a subset of imperfectives, expressing incomplete action whose completion is presented as a sequence of moments, or as cyclical [action] (Koneski, 2004: 369-370). Furthermore, an aspectual pair is defined as the correlation of two verbs, different in their aspect but identical in their lexical meaning, which form a mutual word-

\footnotetext{
${ }^{1}$ A more elaborate version of this paper can be found in Proceedings of the 10th MacedonianNorth American Conference on Macedonian Studies (held from $30^{\text {th }}$ August to 1st September 2018 in Ohrid, pending publication).
} 
forming relationship (Koneski, 1999b: 242). Exceptions to this definition are suppletive aspectual pairs such as: гледа - види, вели - рече, слуша чye, etc. Aspectual pairs are formed (1) by prefixing an imperfective (пече $=>$ ис|пече, perfectivation), and (2) by suffixing a perfective (превед|е + ува = преведува, imperfectivation).

Having in mind Koneski's definition of aspectual pairs and considering that verbs are an open group, the verbal system becomes an unlimited array of aspectual pairs, each one generated by imperfectivation (by suffixation or by vowel change) or by perfectivation (by one of the prefixes and, rarely, by means of the suffix $-\mathrm{He}$ ).

Since perfectivation ${ }^{2}$ changes the derivative's (1) lexical meaning, (2) aspectual and lexical meaning, and at times, (3) aspectual meaning (Koneski, 1999b: 241), imperfectivation proves to be the only derivation method that generates a consistent array of absolute aspectual pairs. Since suffix-generated aspectual pairs are characterized by greater regularity in comparison to their prefix-generated counterparts, "imperfectivation may be seen as a grammatical way of forming lexically identical aspect-correlative verb forms <...>." (Koneski, 1999b: 245) It is this regularity of imperfectivated derivatives that has occasioned the concept of aspectoriented conjugation (AOC).

Using software technologies, I have conducted statistical research on the aspectual nature of the Macedonian verb system, which covered the following phases: (1) collecting a verb corpus, (2) aspectual labelling, (3) establishing inter-verb aspectual relationships, (4) analysis and conclusion.

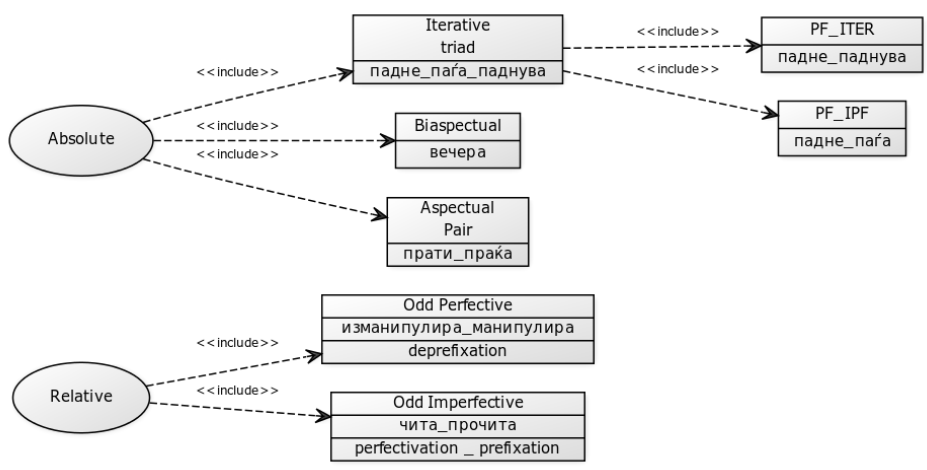

Fig. 1 - Aspectual Relationships

\footnotetext{
${ }^{2}$ Since there are no specialized prefixes for purely aspectual function, there are no formal criteria for distinguishing prefixed aspectual pairs (Koneski, 1999b: 246).
} 
As Figure 1 shows, aspectual relationships in Macedonian can be broadly divided into two groups: absolute and relative. A verb that has absolute aspectual relationship with another one is said to match Koneski's definition of an aspectual pair, i.e. it establishes aspectual relationship with another verb, with which it has identical lexical meaning but is marked by opposite aspect. Another type of absolute aspectual relationship is held by biaspectuals and iterative triads.

Relative aspectual relationships are, conversely, formed by verbs that are not lexically identical but are said to make up contextual aspectual pairs by means of what K. Koneski calls an empty prefix. This arises when prefixing an odd (non-prefixed) imperfective, which merely introduces aspectual change to it (e.g. чита > про|чита). The opposite holds in odd perfectives and prefixed biaspectuals, where imperfectivation occurs by means of deprefixation. Note that it is impossible to use the imperfectivation suffix ува recursively in odd perfectives ending in -ува and in perfectives rooted

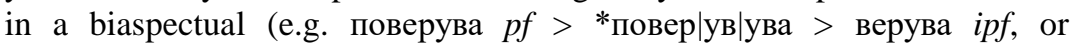
изманипулира $p f>$ * изманипулирува? (poor style) > манипулира $b s p$ ).

Our starting hypothesis is that AOC will be possible among the huge majority of verbs having absolute aspectual relationship with another verb. Hence, the conjugation input will be a $p f-i p f$ type aspectual pair (e.g. успее - успева).

\section{Research and results}

In the first phase, 20706 verbs were collected and labelled by aspect. The verb corpus has been compiled by gathering lexical and aspectual information from the following sources: Rechnik na makedonskiot jazik: so srpsko-hrvatski tolkuvanja (Dimitrovski, 1994), Tolkoven rechnik na makedonskiot jazik, vols. I - VI (Koneski, 2003-2014) and Pravopisen rechnik na makedonskiot literaturen jazik (Koneski, 1999). The Labels used in this phase were: imperfective (ipf), perfective ( $p f)$, biaspectual $(b s p)$ and iterative (iter) as a subset of the imperfective aspect. The following scenarios defined the possible aspectual relationships one or more verbs had:

- $\quad$ odd imperfective (odd ipf, yuma),

- $\quad$ odd perfective (odd $p f$, поверува),

- $\quad$ aspectual pair ( $p f+i p f, A A R$, преведе - преведува),

- $\quad$ biaspectual verb (bsp, e.g. имитира, вечера) and

- $\quad$ iterative triad (ipf $+p f+$ iter, iterative arrays type лежи - легне легнува, паѓa - падне - паднува еtc). 
Once the verbs were collected, labelled and classified by aspect, corpus analysis followed. The corpus was imported in a MySQL database. The phpmyadmin graphical user interface, as part of the XAMPP package, was used to interact with the database server. Results of the analysis were obtained by using queries written in the SQL programming language. PCREs were used to submit queries referring to aspectual and verb group markers. The database server returned query results translated into the following figures:

\begin{tabular}{|l|c|l|}
\hline \multicolumn{3}{|c|}{ Overview of verbs processed (A-Ш) } \\
\hline Total verbs & $100 \%$ & 20706 \\
\hline Total pairs & $92.59 \%$ & 19717 \\
\hline Total odd $^{3}$ verbs & $7.25 \%$ & 1502 \\
\hline
\end{tabular}

\section{Fig.2-Overview of verbs processed}

Of totalling 20706 verbs of all three verb groups, $92.59 \%$ or 19171 verbs have absolute aspectual relationship with at least one other verb in the system. This relation type covers binary aspectual pairs, biaspectuals (which make up an aspectual pair by themselves) and iterative triads (a combination of perfective, imperfective and iterative verb, e.g. naдне паѓa - паднува). Absolute aspectual relationship is here understood as the semantic compatibility of two verbs to make up a pure aspectual pair without the need to use prefixation to obtain the so-called 'empty' prefix effect (е.g. верува - поверува, чита - прочита). Thus, absolute aspectual pairs contain members differing in aspect only whereas their lexical meaning is identical (cf. Koneski's definition of aspectual pair).

The largest subset in this group is made up of absolute pairs (binary ones of the type фати - фаќ, роди - раѓа, преведе - преведува, etc.), which make up $79.75 \%$ or 16514 verbs. Iterative triads make up another subgroup (6.45\% or 1395 verbs). Not only does their structure meet the criterion for an aspectual pair, but also it allows for two aspectual pairs with variable iterative semantics to be generated from one iterative triad. The naдне паѓ - паднува triad, for instance, can generate the aspectual pair (1) падне - naѓa, and the iterative pair (2) падне - паднува.

Biaspectuals (6.09\% or 1262 verbs) also make up a subgroup which can be claimed to make up aspectual pair with themselves, owing to their dual relationship with the perfective and the imperfective aspect. For instance, the biaspectual вечера (bsp) can be represented by the formula

\footnotetext{
${ }^{3}$ The term odd verb is used to refer to verbs that do not have absolute aspectual relationship with any other verb.
} 


$$
E(b s p)=p f(V) \& i p f(V),
$$

where the biaspectual event $(\mathrm{E})$ is realized via a perfective $(\mathrm{V})$ and an imperfective (V) (Е.g., Вчера тој вечера слабо (Aorist) - Вчера тој вечераше иела ноќ (imperfect)). As can be seen in the above example, the perfective stem and imperfective stem in biaspectuals overlap, hence their aspectual bivalence. Fig. 3 features an overview of aspectual pairs.

\begin{tabular}{|l|l|l|}
\hline Total pairs & $92.59 \%$ & 19171 \\
\hline Absolute pairs & $79.75 \%$ & 16514 \\
\hline Biaspectuals & $6.09 \%$ & 1262 \\
\hline Iterative triads & $6.74 \%$ & 1395 \\
\hline
\end{tabular}

Fig. 3-Overview of aspectual pairs

\section{Figuring out odd verbs}

The remaining verbs, provisionally called odd, are verbs that do not have their own absolute aspectual pair but have a contextual (relative) aspectual relationship. Relative aspectual relationship is understood as the semantic compatibility of one verb to make up a pseudo-aspectual pair (imperfective - perfective) with another verb, with which it is not usually lexically but with which it may form a contextual aspectual pair by means of prefixation, or by suppletion (e.g., глед $a \Rightarrow в и д и$, or by one of the available prefixes e.g., копа - ископа, чита - прочита, верува поверува). It is called relative or pseudo-aspectual because prefixes can never generate pure aspectual distinction since they are burdened with their own semantics. Such among the imperfectives are $7.25 \%$ of the analysed corpus or 1502 verbs of all three groups. Some of the most frequently used verbs in Macedonian can be found in this group. Fig. 4 shows the overview of odd imperfectives relative to the total verb corpus.

\begin{tabular}{|l|c|c|}
\hline Total verbs & $100 \%$ & ${ }^{2070}$ \\
\hline Total odd imperfectives & $7.25 \%$ & 1502 \\
\hline Odd -a verbs & $2.38 \%$ & 492 \\
\hline Odd -e verbs & $0.95 \%$ & 196 \\
\hline Odd - и verbs & $3.93 \%$ & 814 \\
\hline
\end{tabular}

Fig 4-Aspect-Odd Verbs 
Although the odd $-\mathrm{e}$ group $(0.95 \%$ or 196 verbs) is the smallest among the odd imperfective verb groups, its members are among the most frequently used verbs and, as non-prefixed imperfectives, have the most productive prefix-derivational combinations. This feature makes them the very core of the verbal system. Their perfective stems have been largely codified in the Macedonian Orthographic Dictionary. They formally behave as biaspectuals, because their perfective stem can be derived from their imperfective stem, and having both, they can develop a full paradigm. Modern native speakers, however, rarely make an independent use of this verb group's perfective stems. Instead, this odd verb group makes up aspectual pairs by prefixation (e.g. брише $=>$ *брншав $=>$ из-брише (избришав) (Koneski, 1999: 33)). What is also interesting about the odd-e verb group is that, although the independent use of their perfective stems is restricted, they are nonetheless widely found within other verbs derived by prefixation: e.g., in the standard language, the codified aorist form of the verb, e.g., корне with the meaning "1. Pull (something, especially a tree or plant) out of the ground."- Вчера *жрнав голем корен во дворот. However, the stem -корна 6 is used in all aorist forms of the prefixed perfective derivative $u c+$ корне (искорнав, искорна, искорнавме, искорнавте, искорнаа, е.g. Вчера искорнав голем корен во дворот), as well as in other prefixed derivatives of the verb корне (откорне $=>$ откорнав). This is an example of relative aspect relationship between корне and искорне in order to create a contextual aspectual pair корне искорне. Other examples of relative aspectual pairs of the odd e-group are: мие - измие, пиуе - опиуе, сее - посее, стине - остине, пие - испие, мете - измете/смете, брише - избрише еtс.

Odd a-group imperfectives amount to $2.38 \%$ or 492 verbs. It is difficult to speak of a perfective stem in this group because the a-verb group in Macedonian does not have aorist subgroups. Therefore, this verb group can only make up relative aspectual pairs by using one or more prefixes.

Odd и-group imperfectives amount to $3.93 \%$ or 814 verbs of the analysed verb system. Their situation is somewhat varied: on the one hand, there is a small group of non-prefixed и-group imperfectives whose stem ends in a consonant: носи (носив), брбори (брборив), брани (бранив), бележи (бележив/бележав), лежи (лежав), дели (делив), држи (држив/ав), седи (седов) and another group of и-verbs whose stem ends in a vowel, such as: брои (броив/бројав), гнои (гноив/гнојав), гои (гоив/гојав), крои (кроив/кројав), пои (поив/појав), стои (стоив/стојав), строи (строив/стројав), таи (таив), постои (постоив/постојав), whose perfective stems have been codified but which are hardly ever or at all used by native speakers. On the other hand, the rest of this verb group 
has been codified as imperfectives only, and in practical speech they make up relative perfective pairs by prefixation.

\section{Aspect-oriented conjugation}

The above statistical findings have led to the conclusion that aspectual pairs should be the starting point in approaching the problem of aspectual conjugation in Macedonian.

Let's consider the absolute aspectual pair npam $\mid u$ - npaḱ $\mid a^{4}$ containing npam- as its perfective stem and npaḱ- as its imperfective stem. The following simple forms have been generated from the perfective stem: present subjunctive $($ nрam $|\mathbf{a}| \mathbf{M})$, aorist (прат|и|в), perfective l-form (прат|и|л), perfective subjunctive 1-form (прат|е|л), perfective imperative mood (прат|и), perfective imperative plural (прат|е|те), perfective past subjunctive (прат|е|в) and perfective verbal adjective (прат|е|н / прат|е|на / прат|е|но/ прат|е|ни).

The following forms have been generated from the imperfective stem: present indicative tense (праќ $|\mathrm{a}| \mathrm{M})$, imperfect (праќ $|\mathrm{a}| \mathrm{B}$ ), imperfective 1form (праќ|a|л), imperfective imperative mood (праќ|a|j), imperfective imperative plural (праќ|a|jтe), verbal adverb (праќ|a|jќи), imperfective verbal adjective (праќ|a|н / праќ|a|на / праќ|a|но/ праќ|a|ни), and verbal noun (праќ|a $\mid \mathrm{њe})$.

Among the generated imperfective basic forms, note the overlap between indicative and subjunctive present праќ-a-м, imperfect праќ-а-в and l-forms праќ-а-л which account for the possibility of imperfectives to form indicative forms and subjunctive da-constructions, which is not the case with perfectives.

Once we have generated simple forms of both stems, we could proceed to generate complex indicative verb forms. To this end, use will be made of the present auxiliary verb sum-forms (сум, си, е, сме, сте, се) and their imperfect counterparts (бев, беше, беше, бевме, бевте, беа) as well as the fixed particle $\kappa^{\prime}$.

Figure 5, in which arrows are used to indicate the respective stems used to generate indicative tenses, describes the procedure for generating indicative forms.

\footnotetext{
${ }^{4}$ Vertical pipe (|) is used to delimit verb stems from subsequent inflectional elements.
} 


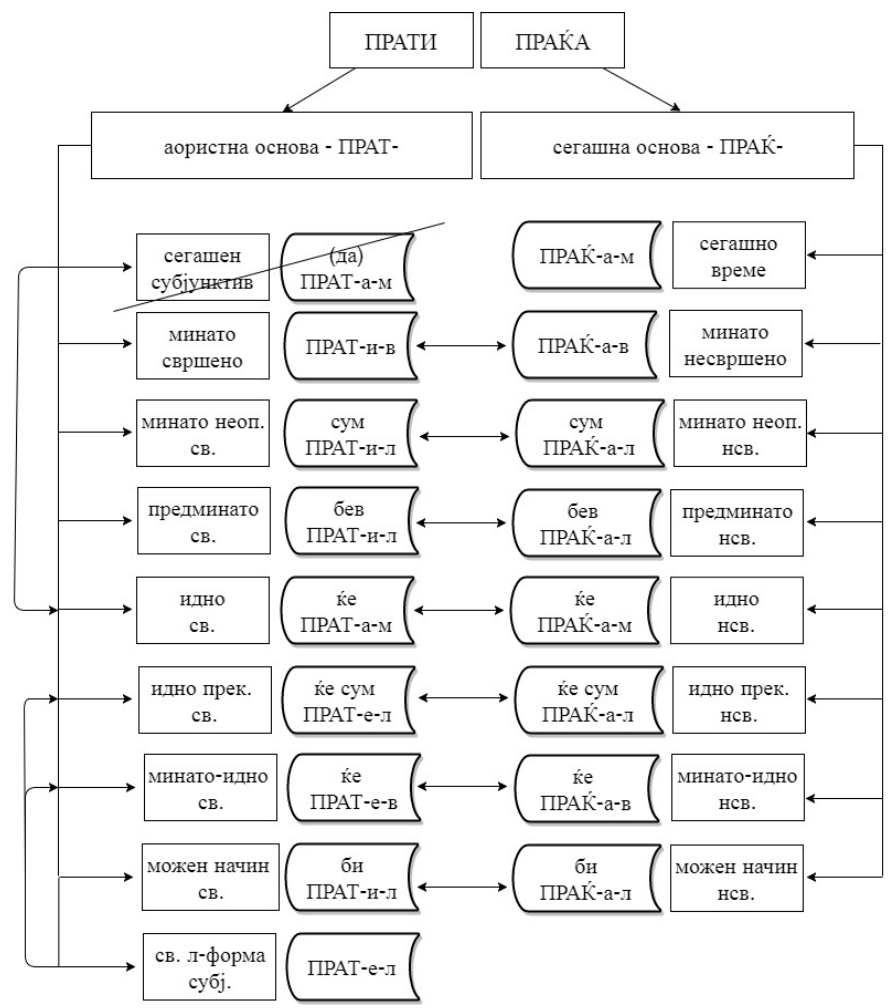

Figure 5-Generating indicative tenses and the conditional mood

Each tense and mood utilizes the perfective and imperfective stem. Both stems participate in building complex forms in the perfect, pluperfect, future, future-in-the-past, future reported tense and conditional mood. Perfectives cannot directly derive verbal nouns, verbal adverbs and negative imperative forms (не прати is today regarded as archaic and is not used in contemporary speech and writing). Figure 6 shows the complete aspectual paradigm of the прати - праќa pair, barring da-constructions, are featured in the full online conjugator at asp.vigna.mk. 


\begin{tabular}{|c|c|c|c|}
\hline Лице/Време & Сегашно време (ipf) & Минато свршено (pf) & Минато несвршено (ipf) \\
\hline Јас & праќам & пратив & праќав \\
\hline Ти & праќаш & прати & праќаше \\
\hline Тој/таа/тоа & праќа & прати & праќаше \\
\hline Ние & праќаме & пративме & праќавме \\
\hline Вие & праќате & пративте & праќавте \\
\hline Тие & праќаат & пратија & праќаа \\
\hline
\end{tabular}

\begin{tabular}{|c|c|c|c|c|c|c|}
\hline Време & \multicolumn{2}{|c|}{ Минато неоределено } & \multicolumn{2}{|c|}{ Предминато } & \multicolumn{2}{|c|}{ Идно } \\
\hline Лице/Вид & свршено & несвршено & свршено & несвршено & свршено & несвршено \\
\hline Јас & сум пратил & сум праќал & бев пратил & бев праќал & ќе пратам & ќе праќам \\
\hline Ти & си пратил & си праќал & беше пратил & беше праќал & ќе пратиш & ќе праќаш \\
\hline тој/таа/тоа & пратил & праќал & беше пратил & беше праќал & ќе прати & ќе праќa \\
\hline Ние & сме пратиле & сме праќале & бевме пратиле & бевме праќале & ќе пратиме & ќе праќаме \\
\hline Вие & сте пратиле & сте праќале & бевте пратиле & бевте праќале & ќе пратите & ќе праќате \\
\hline Тие & пратиле & праќале & беа пратиле & беа праќале & ќе пратат & ќе праќаат \\
\hline
\end{tabular}

\begin{tabular}{|c|c|c|c|c|c|c|}
\hline \multirow{2}{*}{$\begin{array}{c}\text { Време } \\
\text { Лице/Вид }\end{array}$} & \multicolumn{2}{|c|}{ Минато-идно } & \multicolumn{2}{|c|}{ Идно прекажано } & \multicolumn{2}{|c|}{ Можен начин } \\
\hline & свршено & несвршено & свршено & несвршено & свршен & несвршен \\
\hline Jac & ќе пратев & ќe праќав & ќе сум прател & ќe сум праќал & би пратил & би праќал \\
\hline Ти & ќе пратеше & ќe праќаше & ќе си прател & ќe си праќал & би пратил & би праќал \\
\hline Тој/таа/тоа & ке пратеше & ќe праќаше & ќе прател & ќe праќал & би пратил & би праќал \\
\hline Ние & ќе пратевме & ќе праќавме & ќе сме прателе & ќe сме праќале & би пратиле & би праќале \\
\hline Вие & ќе пратевте & ќе праќавте & ќe сте прателе & ќe сте праќале & би пратиле & би праќале \\
\hline тие & ќе пратеа & ḱe праќaа & ќе прателе & ќe праќале & би пратиле & би праќале \\
\hline
\end{tabular}




\begin{tabular}{|c|c|c|c|c|}
\hline \multirow[t]{2}{*}{ време/форма } & \multicolumn{2}{|c|}{ прати } & \multicolumn{2}{|c|}{ праќa } \\
\hline & едн. & мн. & едн. & мн. \\
\hline проста заповед & прати & пратете & праќaj & праќајте \\
\hline одречна заповед & $\emptyset$ & $\emptyset$ & не праќај & не праќајте \\
\hline Заповед „Немој“ & немој да пратиш & немојте да пратите & немој да праќаш & немојте да праќате \\
\hline Л-форма & $\begin{array}{l}\text { прател } \\
\text { пратил }\end{array}$ & $\begin{array}{l}\text { прателе } \\
\text { пратиле }\end{array}$ & праќал & праќале \\
\hline \multirow{3}{*}{ Глаголска придавка } & пратен & \multirow{3}{*}{ пратени } & праќан & \multirow{3}{*}{ праќани } \\
\hline & пратена & & праќана & \\
\hline & пратено & & праќано & \\
\hline Глаголска именка & $\emptyset$ & $\emptyset$ & праќaњe & праќања \\
\hline Глаголски прилог & \multicolumn{2}{|r|}{$\emptyset$} & \multicolumn{2}{|c|}{ праќајќи } \\
\hline
\end{tabular}

Figure 6 - Full paradigm of the nрати - npaḱa aspectual pair

The advantages of the full aspectual paradigm are in that both aspects of the event can be displayed in one place.

Aspect-oriented conjugation has its shortcomings related to the polysemy of non-prefixed odd imperfectives ${ }^{5}$.

\section{Closing Thoughts}

Elaborating the features of aspect-oriented conjugation in Macedonian has led to an aspectual conjugator located at the free internet URL asp.vigna.mk.

Regardless of the detailed information the conjugator gives, odd imperfectives still pose an evident problem for foreign learners. In spoken and written practice, all odd imperfectives of all verb groups make up aspectual pairs by prefixation and since there is more than a dozen of prefixes, it will be still difficult for foreign learners to pick the most appropriate aspectual pair member for an odd imperfective as prefixes change a verb's lexical meaning.

\footnotetext{
${ }^{5}$ Foreign students of Macedonian will have to rely on some kind of further aid to figure out the best contextually appropriate prefix to build aspectual pairs as far as these are concerned. An attempt to compile a relative pair list to non-prefixed imperfectives has been made by Kiril Koneski (1999b).
} 


\section{Литература}

Димитровски, Тодор (1994). Речник на македонскиот јазик: со српскохрватски толкувања [Фототипско изд.]. Блаже Конески (ед.). Скопје: Детска радост.

Конески, Кирил. (Ед.) (2003-2014). Толковен речник на македонскиот јазик, IVI. Скопје: Институт за македонски јазик „Крсте Мисирков“.

Конески, Блаже (2004). Граматика на македонскиот литературен јазик. Скопје: Просветно дело АД, Детска радост.

Конески, Кирил. (1999)а. Правописен речник на македонскиот литературен јазик. Скопје: Просветно дело.

Конески, Кирил. (1999)б. За македонскиот глагол. Скопје: Детска радост.

\section{References}

Dimitrovski, Todor (1994). Rechnik na makedonskiot jazik: so srpsko-hrvatski tolkuvanja [Dictionary of the Macedonian language: Serbo-Croatian interpretations]. Blazhe Koneski (Ed.). Skopje: Detska radost. (In Macedonian.)

Koneski, Kiril. (Ed.) (2003-2014). Tolkoven rechnik na makedonskiot jazik [Dictionary of the Macedonian language]. I-VI. Skopje: Institut za makedonski jazik „Krste Misirkov“. (In Macedonian.)

Koneski, Blazhe. (2004). Gramatika na makedonskiot literaturen jazik [Grammar of the Macedonian literary language]. Skopje: Prosvetno delo AD, Detska radost. (In Macedonian.)

Koneski, Kiril. (1999)a. Pravopisen rechnik na makedonskiot literaturen jazik [Dictionary of Macedonian Literary Language]. Skopje: Prosvetno delo. (In Macedonian.)

Koneski, Kiril. (1999)b. Za makedonskiot glagol [About Macedonian verb]. Skopje: Detska radost. (In Macedonian.) 